\title{
Assessment of heavy metal toxicity using a luminescent bacterial test based on Photobacterium sp. strain MIE
}

\begin{abstract}
Toxicity evaluation of wastewater, polluted sediment and water streams is a very crucial aspect of environmental pollution monitoring. In this work, a newly developed luminescent bacterial test using a tropical luminescent bacterium, Photobacterium sp. strain MIE was used to assess the toxicity of several heavy metals using a 15-min assay format. The assessment was carried out by exposing strain MIE to different concentrations of heavy metals ranging from 0.001 to $200 \mathrm{mg} / \mathrm{L}$ in a DTX microplate 96 wells. The toxicity result based on the inhibitory concentration $(\mathrm{IC} 50)$ was $\mathrm{Hg}(0.053 \mathrm{mg} / \mathrm{L})>\mathrm{Ag}(0.12 \mathrm{mg} / \mathrm{L})>\mathrm{Cu}(0.85 \mathrm{mg} / \mathrm{L})>\mathrm{Ni}(12.32$ $\mathrm{mg} / \mathrm{L})>\mathrm{Zn}(18.72 \mathrm{mg} / \mathrm{L})>\mathrm{Cr}(26.02 \mathrm{mg} / \mathrm{L})$. Principal Component Analysis (PCA) and Agglomerative Hierarchical Clustering (AHC) analyses showed the sensitivity (IC50) of strain MIE to several toxic heavy metals are comparable to the commercial luminescent assay, Microtox ${ }^{\mathrm{TM}}$ as both clusters together making it a good choice for an alternative near-real-time monitoring of heavy metals. The sensitivity of strain MIE towards heavy metals was proven through field trial works on several heavy metal-polluted sites in Malaysia. Thus, it is a good candidate as an early detection system for heavy metals in aquatic bodies in tropical countries.
\end{abstract}

